Тимошенко Р. І., д.військ.н., с.н.с.;

Федянович Д.Л., к.військ.н., с.н.с.;

Шпура М. І., к.військ.н, с.н.с.;

Андріянова Н. М.

Центр воєнно-стратегічних досліджень Національного університету оборони України імені Івана Черняховського, Київ

\title{
Проблемні питання розроблення сценаріїв воснних (бойових) дій в інтересах запобігання воснним конфліктам
}

Резюме. В статті наведені результати аналізу проблемних питань визначення структури та змісту сценарію воєнного конфлікту (сценарію планування) в інтересах запобігання воєнних конфліктів, виконанні заходів оборонного планування орієнтованого на спроможності.

Ключові слова: конфліктна ситуація, воєнний конфлікт, сценарій воєнного конфлікту, сценарій планування, сценарій воєнних (бойових) дій угруповання військ (сил).

Постановка проблеми. $\mathrm{y}$ процесі формування та планування оборонної політики за потреби опрацювати ситуації в залежності від обстановки й оперативних показників використовують сценарії. Під ситуацією розуміється сукупність умов та обставин, що створює певне середовище [1]. У нашому випадку прикладом конфліктної ситуаціє $є$ воєнний конфлікт. Сценарії планування не призначені для пророкування майбутніх ситуацій та результатів. Скоріше вони використовуються у процесі розробки організаційної структури збройних сил i оборонних планів, для потреб оперативного планування та обгрунтування вимог до спроможностей. Спроможність у широкому сенсі визначається як здатність до виконання певних завдань. За результатами попередніх досліджень [2] сценарний підхід використовують для опрацьовування можливих конфліктних ситуацій, які можуть виникати або вже виникли в результаті розвитку воєнно-політичної обстановки (ВПО).

На етапі визначення вимог до майбутніх збройних сил для планування розробляється сценарій, який по суті і $є$ сценарієм воєнного конфлікту оскільки стосується ситуації у якій можуть бути застосовані війська (сили). Під терміном сценарій воєнного конфлікту розуміється прогнозний опис можливого початку, розвитку, завершення i наслідків збройної боротьби на основі оцінки характеру сучасних воєнних конфліктів і геополітичного положення держави. У ньому не конкретизуються в деталях форми та способи ведення воєнних (бойових) дій. Для кожного сценарію планувальники розробляють декілька варіантів (переліки) спроможностей, які плануються до застосування. Тобто призначення сценарію планування полягає у тому, щоб знайти відповідь, що потрібно зробити для досягнення бажаного результату у воєнному конфлікті.
У той же час, відповідно до керівних документів, що регламентують порядок роботи органів військового управління (ОВУ) під час визначення замислу операції (бойових дій) розробляється декілька альтернативних варіантів (способів) ऑiі ведення. Кількісні значення показників для порівняння цих варіантів (способів) ведення операції (бойових дій) можуть бути отримані за допомогою моделювання. Опис умов для оцінювання ефективності альтернативних варіантів ведення операції (бойових дій) прийнято називати сценарієм воєнних (бойових) дій у якому вже деталізуються способи застосування угруповання військ (сил) [3]. Тобто, на теперішній час вживаються різні терміни: сценарій планування, сценарій воєнного конфлікту (або конфліктної ситуації) та сценарій воєнних (бойових) дій. Всі вони розробляються 3 різною метою, мають різну структуру, зміст та призначення. Найбільш складним завданням, на наш погляд, $\epsilon$ розроблення сценаріїв воєнних (бойових дій). Складність їх розроблення обумовлюється необхідною деталізацією вихідних даних для здійснення кількісної та якісної оцінки визначених для порівняння варіантів (способів) ведення операції (бойових дій), що складають його основу.

Аналіз останніх досліджень i публікацій. Аналіз останніх досліджень [3-6] показав, що в них достатньо повно розкривається порядок i послідовність розроблення сценарію для оцінювання ефективності можливих варіантів застосування військ (сил) в операції (бойових діях). Як недолік, у [4] визначається, що в них не в повній мірі розкриті питання щодо урахування можливої зміни часткових завдань військ противника у воєнному конфлікті, а також не 
визначений механізм коригування порядку i послідовності виконання часткових оборонних завдань угрупованням своїх військ (сил) під час поетапного моделювання бойових дій протиборчих сторін.

Для вирішення цього проблемного питання у [4] запропоновано використовувати метод прогнозування процесів, що базується на методології сценарного аналізу соціальноекономічних систем. Сутність цього методу полягає в створені базисного сценарію динаміки процесу, що розглядається, як послідовний вибір експертно-значущих проміжних станів (етапи операції). На думку авторів використання математичних методів для вибору найбільш доцільних (вірогідних) “мікросценаріїв" на кожному визначеному експертами етапі операції (бойових дій) дозволить усунути невизначеності і суперечливості, що можуть виникнути у експертів під час їх розроблення. 3 цим не можна не погодитися.

Разом 3 цим, такий підхід цілком виправданий, коли війська (сили) протиборчих сторін використовують для досягнення воєнностратегічних цілей класичні форми та способи воєнних дій, а для оцінки ефективності варіантів застосування військ (сил) можуть бути використані наявні математичні моделі, наприклад, модель загальновійськового бою (операціi). Сьогодні ж воєнний конфлікт може розпочатися 3 мирних антиурядових акцій i, як показують останні події у світі, завершується жорстокою громадянською війною і зовнішнім втручанням інших, не обов'язково сусідніх, держав або багатонаціональних сил не переростаючи у відкрите збройне протистояння угруповань збройних сил сторін учасників конфлікту.

Метою статті с визначення проблемних питань розроблення сценаріїв воєнних (бойових) дій, уточнення призначення, структури і змісту понять сценарій воєнного конфлікту та сценарій воєнних (бойових) дій.

Актуальність статті обгрунтовується тим, що $з$ одного боку, розробка та аналіз можливих сценаріїв воєнних (бойових) дій, дозволяє визначати як буде розвиватися активна фаза воєнного конфлікту, в залежності від прийнятих рішень, та у подальшому запропонувати декілька варіантів його вирішення для досягнення потрібного результату. 3 іншого боку сценарій воєнних (бойових) дій дозволяє своєчасно визначити ризики та небезпеки, які можуть виникнути при прийнятті того чи іншого варіанту замислу застосування військ (сил) для врегулювання (локалізації, нейтралізації) воєнного конфлікту.

Викладення основного матеріалу. Відомо, що сценарії розвитку будь яких ситуацій дають фахівцям, які їх розробляють, можливість визначити тенденції їхнього розвитку, взаємозв'язки між діючими факторами та сформувати загальне уявлення про наслідки. Співставлення i оцінка можливих варіантів розвитку конфліктної ситуації в залежності від прийнятого рішення та факторів, які не залежать від нього, але впливають на іiі розвиток (наприклад, дії протилежної або третьої сторони у конфлікті) та їх всебічне урахування сприяють прийняттю раціонального рішення щодо іiі врегулювання (локалізації, припинення, ліквідації).

Не виникає сумнів, що метод сценаріїв передбачає створення відповідних технологій (алгоритмів) їх розробки, які забезпечують більш високу ймовірність вироблення доцільного (ефективного) замислу та зведення очікуваних втрат до мінімуму. А отже, спроможно-орієнтований сценарій воєнних (бойових) дій повинен враховувати найбільш важливі фактори, які можуть вплинути на розвиток конфліктної ситуації [2].

Сутність процесу розроблення сценарію воєнних (бойових) дій полягає у встановленні на основі аналізу багатьох факторів логічної послідовності подій, що можуть виникнути у цілком конкретній ситуації з метою визначення альтернатив (варіантів) іiі розвитку та частково можливих наслідків (у вигляді втрат угруповань військ (сил) сторін, економічного потенціалу, частини території тощо).

По суті фактори, які можуть вплинути на перебіг воєнного конфлікту та іiі кінцевий результат визначають його змістовну частину. У свою чергу розкриття змістовної частини у більшості випадків $є$ надскладним завданням для розробників сценарію. У першу чергу, це пов'язане 3 тим, що дуже складно передбачити взаємовплив інформаційно-психологічного протиборства сторін конфлікту, вплив іррегулярних формувань, кримінальних банд, приватних військових кампаній, легіонів іноземних найманців, підрозділів спецслужб, а також військових контингентів міжнародних організацій і коаліцій на вирішенні конфлікту. Тому, для розроблення базисного сценарію воєнних (бойових) дій у прогнозованому воєнному конфлікті, зміст якого викладений в $[5,6]$, повинен бути доповнений додатковими елементами.

Перш ніж перейти до структури та змісту сценарію воєнних (бойових) дій у прогнозованому воєнному конфлікті $\epsilon$ доцільним уточнити деякі поняття i терміни. Сьогодні при дослідженні воєнних конфліктів, під час підготовки та проведення командноштабних навчань, воєнних ігор широко використовуються терміни “сценарій воєнного конфлікту” та “сценарій воєнних (бойових) дій”. 
Необхідно розрізняти терміни “сценарії воєнних конфліктів” і “сценарії воєнних (бойових) дій”. Сценарій воєнного конфлікту може мати декілька сценаріїв (варіантів) ведення воєнних (бойових) дій. Такий висновок можна зробити 3 аналізу загальноприйнятого визначення терміну сценарію воєнного конфлікту, що приведений у роботі [3]. Для усунення плутанини у термінах під час здійснення оборонного планування пропонується користуватися терміном "сценарій воєнного конфлікту", оскільки він охоплює всі фази конфлікту, а не тільки його активну фазу. На рис. 1 приведені різні підходи до структури сценарію воєнного конфлікту. У верхній частині рисунка приведений підхід, що використовується при формування сценарію, який використовують під час оборонного планування заснованого на спроможностях. У нижній частині рис. 1 структура сценарію, що використовується для проведення командноштабних навчань стратегічного та оперативного рівня.

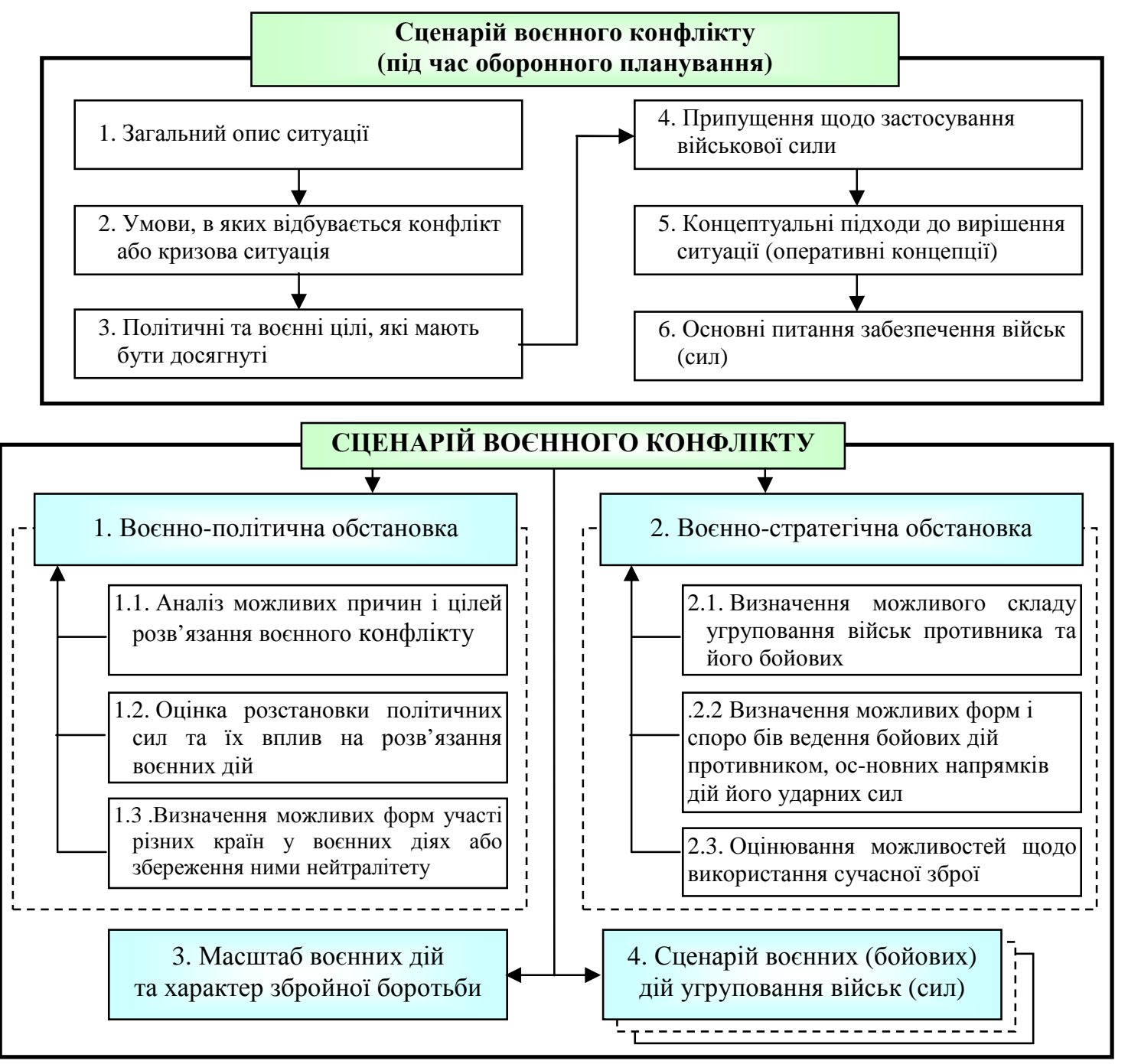

Рис. 1. Порівняння підходів до структури сценарію воснного конфлікту

Як видно 3 рис. 1 для кожного сценарію воєнного конфлікту може розроблятися декілька сценаріїв воєнних (бойових), або інших дій. Вони різняться між собою складом угруповань військ (сил) протиборчих сторін, який залежить від прогнозованого ступеня участі збройних сил сторін у воєнному конфлікті, формами воєнних дій, що можуть використовувати протиборчі сторони для досягнення воєнно-стратегічних (оперативних) цілей, часовими показниками підготовки i ведення воєнних (бойових) дій військ сторін, способами розв'язання збройної агресії (дестабілізації обстановки в районі майбутніх бойових дій), способами ведення операцій (бойових) дій у межах визначених форм застосування угруповань військ (сторін) та іншими.

У загальному вигляді формат сценарію воєнного конфлікту включає короткий опис події, політичні цілі, які буде переслідувати воєннополітичне керівництво держави для врегулювання конфлікту, основні завдання (місії) збройних сил та інших складових сектору оборони і безпеки, умови обстановки та основні вимоги щодо виконання завдань військовими формуваннями. Досвід АТО показав, що невиконання (затримка 3 виконанням) окремих завдань, а також відсутність взаємодії між частинами 
(підрозділами) окремих складових сектору оборони може суттєво вплинути на загальну обстановку в зоні конфлікту.

Обстановка у сценарії воєнного конфлікту відображається як сукупність факторів і умов, у яких буде здійснюватися підготовка та ведення воєнних (бойових) дій. Обстановка, яка відображається у сценарії планування, за масштабом ,зазвичай, $\epsilon$ стратегічною але за деяких умов може бути конкретизована до оперативного рівня, а у окремих випадках - i до тактичного рівня.

Сценарій воєнних (бойових) дій охоплює тільки частину сценарію воєнного конфлікту, яка стосується безпосередньо підготовки, ведення та, частково, наслідків бойового застосування угруповань військ (сил) сторін у формі операцій, бойових дій, боїв та дій іншого характеру у можливому воєнному конфлікті.

Необхідно зазначити, що не завжди сценарій воєнного конфлікту може передбачати шляхи його врегулювання веденням класичних воєнних (бойових) дій. Це пов'язано 3 тим, що сьогодні суттєво зростає роль психологічних, спеціальних та інших видів операцій у збройних конфліктах і локальних війнах. Військові дії у формі операцій, бойових дій, боїв при вирішенні воєнного конфлікту витісняються на другорядне місце у вирішенні воєнного конфлікту [6].

Тому не випадково заходи оперативної підготовки військ (сил), а саме: командноштабні навчання (КШН), воєнні ігри, тренування, а також наукові дослідження 3 питань підготовки та застосування військ (сил) проводяться на фоні певної воєнної обстановки, яка повинна відповідати характеру ймовірних конфліктів, сучасним тенденціям та основним принципам ведення збройної боротьби.

Отже при розробці замислів проведення навчань, тренувань, воєнних ігор виникає потреба враховувати: результати аналізу причин можливого виникнення збройних конфліктів до яких може бути втягнута Україна; ймовірні воєнно-політичні цілі сторін у цих конфліктах; характер і ступень участі в них збройних сил. Результати такого аналізу повинні, на нашу думку, відображатися у сценаріях воєнних (бойових) дій.

Тобто сценарій воєнних (бойових) дій $є$ невід' ємною частиною замислу навчання, у якій конкретизовано характер, фактори та умови в яких здійснюється підготовка і ведення воєнних (бойових) дій угрупованнями військ (сил) для досягнення цілей збройної боротьби у конкретному конфлікті. Основу сценарію воєнних дій складає воєнна обстановка.

Відомо [5], що воєнна обстановка - це сукупність факторів і умов, у яких здійснюється підготовка і ведення воєнних (бойових) дій. За даними $[5,6]$ до основних факторів i умов, у яких здійснюється підготовка і ведення воєнних дій відносяться: склад, угруповання і характер дій військ (сил) противника; стан своїх військ (сил), поставлені завдання, матеріально-технічна забезпеченість; становище і дії сусідів; характер місцевості; кліматичні і гідрометеорологічні умови; пора року і час доби; терміни підготовки до бойових дій і виконання бойових завдань.

Воєнна обстановка по суті складає основу сценарію воєнних (бойових) дій, який розробляється у відповідності до сценарію воєнного конфлікту. Виходячи з вимог керівних документів першочерговим завданням при розробці сценарію воєнного конфлікту $\epsilon$ прогнозування характеру i масштабу воєнних (бойових) дій

Після визначення характеру i масштабу воєнних (бойових) дій визначаються інші елементи сценарію, зміст яких наведений на рис. 2.

Важливим є те, що у сценарії воєнних (бойових) дій повинні конкретизуватися ймовірні форми і способи застосування військ агресора, а також можлива послідовність виконання цих форм на весь період конфлікту. Крім того визначаються адекватні форми та способи застосування угруповань своїх військ.

Форми і способи застосування військ (сил) та ступінь ї участі у конфліктах будуть визначатися, головним чином, метою конфлікту, масштабами воєнних дій та фізико-географічними умовами місцевості в районі конфлікту, воєннополітичною, воєнно-стратегічною обстановкою та наявними бойовими можливостями військ (сил).

Розроблені експертами можливі сценарії воєнних конфліктів в яких можлива участь Збройних Сил України доцільно зводити в єдину базу даних сценаріїв воєнних конфліктів 3 можливістю їх подальшого дослідження та корегування. Наприклад, у деяких публікаціях пропонується сценарії включати до спеціалізованих інформаційно-пошукових систем, пропонуються методики складання сценаріїв 3 використанням ЕОМ. Такі підходи потребують більшої формалізації сценаріїв воєнних конфліктів для їх вивчення та підготовки обгрунтованих пропозицій щодо прийняття рішень на етапі розвитку воєнних конфліктів вищим воєнно-політичним керівництвом держави.

Сценарії воєнних (бойових) дій, що розробляються для проведення воєнних ігор, командно-штабних навчань (тренувань) змістовно містять основні елементи бойової (оперативної) обстановки і є основою для вироблення, тими хто навчається, замислу на операцію (бойові діï). Відповідно до вимог керівних документів замисел виробляється 3 урахуванням (на основі) результатів оцінювання ефективності декількох варіантів (способів) застосування військ (сил). Метою оцінювання ефективності варіантів 
(способів) ведення операції (бойових дій) під час вироблення замислу $\epsilon$ визначення доцільного способу застосування військ (сил), а також уточнення бойового складу угруповання військ (сил).

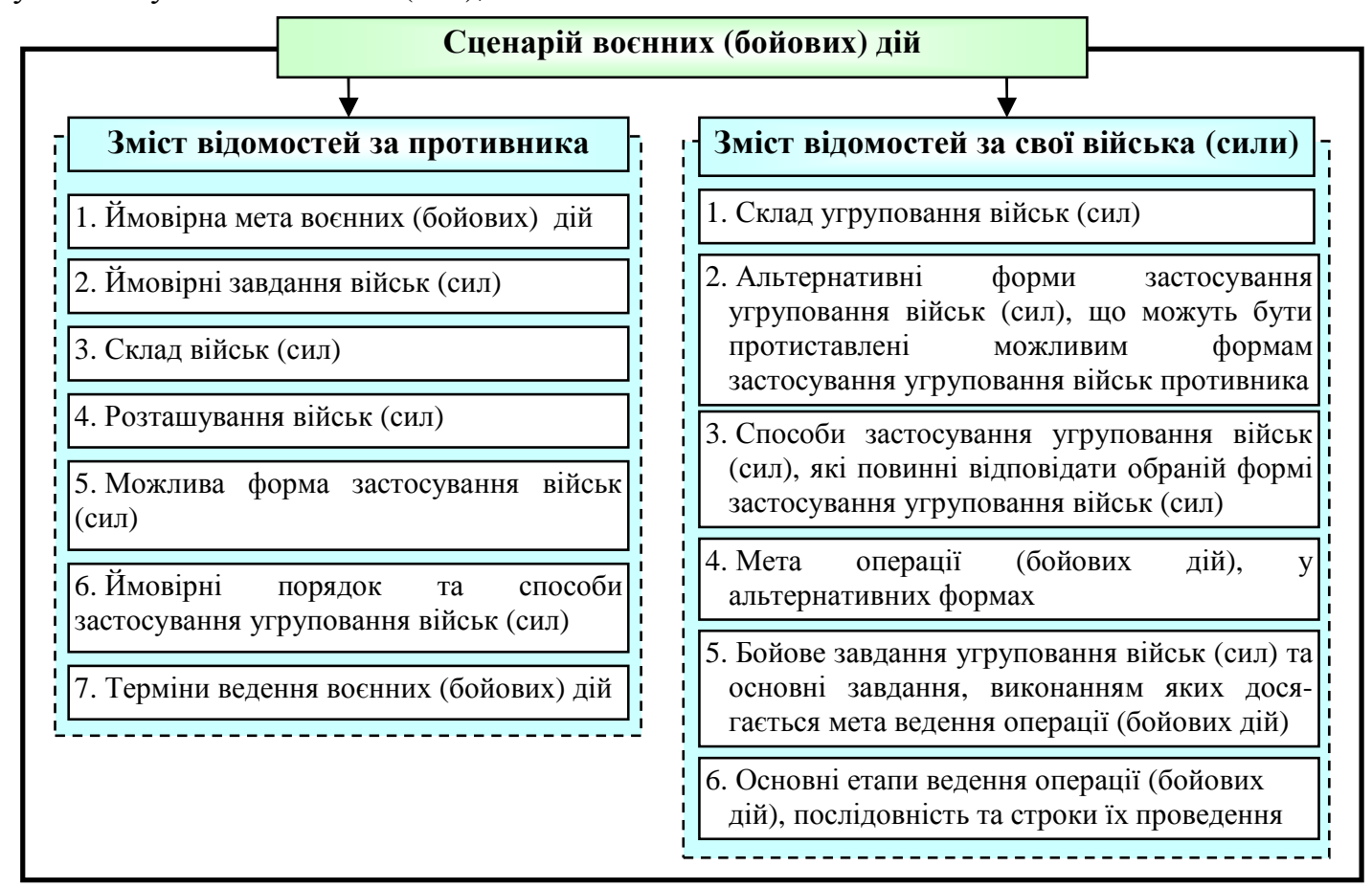

Рис. 2. Структура та зміст сценарію воснних (бойових) дій (варіант)

Можна стверджувати, що сценарії воєнних (бойових) дій, що розробляються безпосередньо для оцінювання ефективності (моделювання операції (бойових дій)) дій військ (сил) в інтересах вироблення замислу операції (бойових дій) суттєво відрізняються за змістом від сценаріїв, що розробляються під час оборонного планування. Їх змістовна частина та ступінь деталізації вихідних даних залежить від можливостей (особливостей) математичних моделей, розрахункових задач, та методик, за допомогою яких здійснюється оцінювання ефективності застосування військ (сил) і тому пропонується називати їх сценаріями для моделювання. У цьому випадку оцінювання ефективності здійснюється 3 дослідницькою метою, наприклад, для вироблення практичних рекомендацій органам військового управління щодо способів ведення операцій (бойових дій), сценарій повинен враховувати не тільки існуючі, а й перспективні тенденції ведення збройної боротьби, а математичні моделі бути адекватні процесам, що досліджуються.

Реалії застосування військ (сил) у воєнному конфлікті завжди більш складні та різноманітні оскільки поєднують у собі як способи застосування військ (сил) для досягнення мети воєнних (бойових) дій так i способів, що не передбачають застосування військової сили [2]. Це в повній мірі підтверджує досвід застосування військ (сил) Збройних Сил України та інших військових формувань та правоохоронних органів спеціального призначення в ході проведення антитерористичної операції. На практиці деякі сценарії (іх окремі елементи) можуть здійснюватися одночасно або послідовно.

\section{Висновки}

1. Наявність сценаріїв воєнних (бойових) дій дозволить обгрунтовано підходити до визначення тематики заходів оперативної підготовки у Збройних Силах України, розробляти замисли проведення воєнних ігор, командно-штабних навчань, тренувань на яких органи військового управління отримують практичні навички 3 підготовки та ведення операцій (бойових дій), що відповідають сучасним тенденціям збройної боротьби.

2. Потреба створення при розробці замислів проведення воєнних ігор, КШН, тренувань та наукових досліджень конкретної оперативної (оперативно-тактичної) обстановки , що складає основу сценарію воєнних (бойових) обумовлює їх практичне значення для підготовки військ (сил) та органів військового управління.

3. Основна функція сценарію воєнних (бойових) дій полягає у виявленні можливих ризиків та наслідків ведення воєнних (бойових) дій в ході розвитку воєнного конфлікту. Розроблений військовими фахівцями широкий спектр можливих альтернативних варіантів локалізації (нейтралізації, ліквідації) воєнних конфліктів дозволить визначати найбільш складні ситуації, що можуть виникнути в ході ведення воєнних (бойових) дій. 
4. Сценарії воєнних (бойових) дій військ (сил), як варіативна складова сценарію воєнного конфлікту (сценарію планування) не повинні бути орієнтовані на існуючий науковометодичний апарат для проведення оцінювання результатів ведення операцій (бойових дій), а навпаки давати можливість виявляти його слабкі сторони та давати поштовх для його удосконалення (розвитку). Особливо це стосується оцінки можливих результатів дій військ (сил) в умовах ведення противником гібридної війни, асиметричних дій, при оцінці доцільності (ефективності) спільних дій військових формувань Збройних Сил України та інших військових формувань та правоохоронних органів спеціального призначення.

5. Перевагою застосування сценарного методу для оцінки результатів застосування угруповань військ (сил) у можливих воєнних конфліктів є те, що метод передбачає розгляд декількох альтернативних варіантів ведення воєнних (бойових) дій на фоні прогнозованої воєнної (оперативно-стратегічної, оперативної) обстановки та дає можливість оцінити переваги та недоліки кожного 3 них для вибору у подальшому найбільш доцільного.

\section{СПИСОК ВИКОРИСТАНОЇ ЛІТЕРАТУРИ}

1. Словник іншомовних слів: 23000 слів та термінологічних словосполучень / Уклад. Л. О. Пустовіт та ін.. - К. : Довіра, 2000. - 1018 с. - (Б-ка держ. службовця. Держ. мова і діловодство).

2. Манойло А. В. Информационно-психологическая война: факторы, определяющие формат современного вооруженного конфликта. - Киев: Материалы V Международной научно-практической конференции "Информационные технологии и безопасность", вип. №8, 2005 г., с. 73-80.

3. Загорка О. М. Аналіз підходів для визначення доцільних форм і способів бойових дій угруповань військ (сил) / Р. І. Тимошенко, I. О. Загорка // Зб. наук. пр. ЦВСД НУОУ ім. Івана Черняховського. - К.: НУОУ. - 2015. - №1(53). - C.8-13.

4. Тимошенко Р. І. Удосконалення методичних положень розроблення сценаріїв воєнних (бойових дій) угруповання військ // Наук. журнал НУОУ ім. Івана Черняховського "Сучасні інформаційні технології у сфері безпеки та оборони”. - К.: НУОУ. - 2015. - № 1 (22) - C. 182-186.

5. Методологічні засади обгрунтування раціональних форм та способів застосування угруповань військ (сил). Воєнно-теоретична праця / В. Г. Радецький, I. С. Руснак, О. М. Загорка та ін./ Під заг. ред С. О. Кириченка / - К.: НАОУ, 2007. - 288 c.

6. Методологічні засади обгрунтування складу угруповання військ (сил) для відбиття агресії: воєннотеоретична праця (монографія) / [В. М. Телелим, О. М. Загорка, Р. І. Тимошенко та ін.]. - К.: НУОУ ім. Івана Черняховського, 2013. - 368 с.

Стаття надійшла до редакції 03.07.2017

Тимошенко Р. И., Д.воен.н., с.н.с.;

Федянович Д.Л.., к.воен.н., с.н.с.;

Шпура Н. И., к.воен.н., с.н.с.;

Андриянова Н.Н.

Центр военно-стратегических исследований Национального университета обороны Украины имени Ивана Черняховского, Киев

Проблемные вопросы разработки сценариев военных (боевых) действий в інтересах предотвращения военных конфликтов

Резюме. В статье приведены результаты анализа проблемных вопросов определения структуры и содержания сценария военного конфликта (сценария планирования) в интересах предотвращения военных конфликтов, выполнения мероприятий оборонного планирования ориентированного на способности.

Ключевые слова: конфликтная ситуация, военный конфликт, сценарий военного конфликта, сценарий планирования. сценарий военных (боевых) действий группировок войск (сил).

\section{R. Tymoshenko, Ds.M, senior researcher;}

D. Fedyanovich, Ph.D, senior researcher;

M. Shpura, Ph.D, senior researcher;

N. Andriianova

Center for Military and Strategic Studies of the National Defence University of Ukraine named after Ivan Chernyhovski, Kyiv

Problematic issues in developing of the scenarios of military (combat) actions in prevention of military conflicts

Resume. The article presents the results of the analysis of problematic issues of determining the structure and content of the scenario of the military conflict (the planning scenario) in the interests of preventing military conflicts, implementing performance-oriented defense planning exercises.

Keywords: conflict situation, military conflict, the scenario of military conflict, the planning scenario, the scenario of military (combat) actions of grouping of troops (forces). 